\title{
Bernard Hamon, George Sand et le prince Napoléon. Histoire d'une amitié
}

\section{Lise Sabourin}

\section{Q OpenEdition}

1 Journals

\section{Édition électronique}

URL : http://journals.openedition.org/studifrancesi/7644

DOI : 10.4000/studifrancesi.7644

ISSN : 2421-5856

Éditeur

Rosenberg \& Sellier

\section{Édition imprimée}

Date de publication : 1 décembre 2009

Pagination : 650

ISSN : 0039-2944

\section{Référence électronique}

Lise Sabourin, «Bernard Hamon, George Sand et le prince Napoléon. Histoire d'une amitié », Studi

Francesi [En ligne], 159 (LIII | III) | 2009, mis en ligne le 30 novembre 2015, consulté le 09 janvier 2021. URL : http://journals.openedition.org/studifrancesi/7644; DOI : https://doi.org/10.4000/studifrancesi. 7644

Ce document a été généré automatiquement le 9 janvier 2021.

\section{(c)}

Studi Francesi è distribuita con Licenza Creative Commons Attribuzione - Non commerciale - Non opere derivate 4.0 Internazionale. 


\title{
Bernard Hamon, George Sand et le prince Napoléon. Histoire d'une amitié
}

\author{
Lise Sabourin
}

\section{RÉFÉRENCE}

Bernard Hamon, George Sand et le prince Napoléon. Histoire d'une amitié,

Vendoeuvres, Lancosme éditeur, 2008, pp. 415.

1 Le prince Napoléon, fils de Jérôme, né en 1822, mort en 1891, surnommé Plon-Plon, quoique condamné comme Bonaparte, notamment pour ses engagements après 1845 , à l'errance européenne - Florence, Gênes, Londres, Livourne -, retrouva en 1848 le droit de vivre dans la patrie à laquelle il s'était toujours montré très attaché. Élu par la Corse à la Constituante, plus tard député puis sénateur républicain de la Sarthe, il protesta par fidélité aux principes de 1789 contre la répression des émeutes par Cavaignac, tout en adhérant à l'action de son cousin (dont il avait été proche dès la jeunesse), mais désapprouva le coup d'État: leur divergence politique fut nette, même si le lien familial maintint leur solidarité.

Cette relation explique celle nouée avec George Sand, venue implorer la clémence de l'empereur (qui lui avait, à sa parution, envoyé L'Extinction du paupérisme et conserva toujours de l'admiration pour son oeuvre) en faveur de ses amis républicains de l'Indre, condamnés à la déportation à Cayenne ou en Algérie. Par l'intermédiaire du comte d'Orsay, elle sollicita donc aussi l'appui du prince Napoléon, alors troisième personnage de la lignée. Leur correspondance devint vite si amicale que le père de Manceau lui dut sa place de gardien au Sénat et que Maurice voyagea jusqu'aux États-Unis en 1861 sur le bateau de celui qui allait devenir le parrain de la petite Aurore.

Les 307 lettres ici présentées sont issues de manuscrits déposés à la Bibliothèque historique de la ville de Paris pour celles du prince, des tomes X à XXIV de l'édition de 
Georges Lubin pour Sand. Outre les commentaires intercalaires de l'annotateur qui mettent en situation leurs échanges, trois annexes viennent apporter des lumières sur Les Prétendants, le feuilleton de George Sand rejeté par "Le Temps", sur les accusations portées contre le prince Napoléon pour son comportement durant les guerres de Crimée, d'Italie et de 1870, enfin sur ses relations avec Cora Pearl.

4 Cette correspondance croisée permet donc surtout de corriger l'image impulsive de cet homme intelligent décrié par ses contemporains, en montrant son amitié durable avec Sand comme fondée sur une libre et franche discussion, mais aussi sur le partage d'une sensibilité liée au mal-être d'un Bonaparte impuissant en politique malgré ses idées avancées. 